\title{
Insurance and Technical Education in National Development - A Wakeup Call.
}

\author{
Sarafa Adebayo Raji
}

\begin{abstract}
Development on national basis is imperative to the sustenance and growth of a Nation. The focus of the paper is on the imperative of insurance and technical education towards national development. The methodology adopted is mainly secondary source, relevant materials were considered and opinion formed. The various development plans in Nigeria from First Development Plan (1962 - 1968) to the most recent of National Industrial Revolution Plan of 2014. Technical education as a strategy for National Development. The experience of countries such as Malaysia, South Korea, Australia and Japan among others as guide for Nigeria. Means of acquiring technical education was also explained. The challenges encountered by the provider of technical education, such peoples attitude to technical education, dearth of teachers and instructors on technical education, funding among others. The paper also took a critical look at the role of insurance in National Development. These roles includes; offering Insurance and financial protection, instilling sense of security and peace of mind, acting as stabilizing factor, acting as institutional investor, and public safety and new product development. Other roles include; enhancing financial security and peace of mind among others. It was further stated that for insurance to function effectively in this role, the government and other stakeholders have a role to play. In conclusion, suggestions for improvement to enable insurance and technical education contribute positively to national development includes Government training Institutions, Parent and Guardian, Development Partners and Employers as stakeholders who must be ready to play a proactive role to achieve a sustainable national development of our dream.
\end{abstract}

Index Terms: Insurance, Development, National Development, Technical Education.

\section{INTRODUCTION}

The quest for National development of a nation rest on the ability of the economy to be able to move from agrarian or primitive to mechanize or advancement in economy. Development is essential and critical to growth and sustenance of any country.

\section{A. Scope of the Study}

The scope of the paper is limited to the role of technical education, especially insurance in national development. The challenges that may hinder the expected role and the way out.

Revised Manuscript Received on September 22, 2019

Raji Sarafdeen Adebayo (Ph.D), Department of Insurance, Federal Polytechnic Offa, Offa, Kwara, Nigeria, Rajisarafa94@gmail.com, $+2348056526876,+2347031292640$

\section{B. Methodology}

The methodology adopted in this paper is mainly secondary source. That is, relevant materials were considered and reviewed and opinion formed.

\section{DEVELOPMENT}

Development as a concept does not lend itself to universal definitions. However, attempts have been made by erudite scholars to conceptualize development. Some of these definitions will be explored for the purpose of this study.

[6] posit that development as an idea that embodies all attempts to improve the conditions of human existence in all ramifications. It implies improvement in material well being of all citizens, not the most powerful and rich alone, in a sustainable way such that today's consumption does not imperil the future, it also demands that poverty and inequality of access to the good things of life be removed or drastically reduced. It seeks to improve personal physical security and livelihoods and expansion of life chances.

[10] equally posit that development is usually taken to involve not only economic growth, but also some notion of equitable distribution, provision of health care, education, housing and other essential services all with a view to improving the individual and collective quality of life [10].

[3] views reported that development as a process of societal advancement, where improvement in the well being of people are generated through strong partnerships between all sectors, corporate bodies and other groups in the society. It is reasonable to know that development is not only an economic exercise, but also involves both socio-economic and political issues and pervades all aspects of societal life.

\section{A. National Development}

National, according to Longman dictionary of contemporary English, refers to a phenomenon that embraces a whole nation. National development therefore can be described as the overall development or a collective socio-economic, political as well as religious advancement of a country or nation. This is best achieved through development planning, which can be described as the country's collection of strategies mapped out by the government. 


\section{B. National Development Plans In Nigeria}

Nigeria as a nation has had series of development plans in Nigeria. Nigeria is permanently hunted by the spectre of development. Its fifty-five years of independence actually are rolling by daily in search of development. The myth of growth and development is so entrenched that the country's history passes for the history of development strategies and growth models from colonial times up to date. No term has been in constant flux as development. This seems the only country where virtually all notions and models of development have been experimented [2].

Immediately after independence, Nigeria has had a number of development plan. The first National Development Plan policy was formulated between 1962 and 1968 with the objectives of development opportunities in health, education and employment and improving access to these opportunities, etc. This plan failed because fifty percent of resources needed to finance the plan was to come from external sources, and only fourteen percent of the external finance was received [14]. Collapse of the first Republic and the commencement of civil war also disrupted the plan. After the civil war in 1970, the second national development plan 1970 to 1974 was launched, the plan priorities were in agriculture, industry, transport, manpower, defense, electricity, communication and water supply and provision of social services [14]. The third plan, covering the period of 1975 to 1980 was considered more ambitious than the second plan. Emphasis was placed on rural development and efforts to revamp agricultural sector. The fourth plan 1981 to 1985 recognized the role of social services, health services, etc. The plan was aimed at bringing about improvement in the living conditions of the people. The specific objectives were: an increase in the real income of the average citizen, more even distribution of income among individuals and socio-economic groups, increased dependence on the country's material and human resources, a reduction in the level of unemployment and underemployment [14].

In the recent past, various strategies for development have also been tried with little or no result; among these were the structural adjustment programme (SAP), Vision 2010, national economic empowerment and development strategy (NEEDS), creation of development centre, etc. currently, seven point agenda of the present administration with vision 2020 without any clear methodological approach towards achieving them. It is obvious that the current results so far are not what development connotes. Also Manufacturers Association on Nigeria (MAN) 4 years strategic plan is to attain efficient production level in the manufacturing sector which hopefully will stimulate increased manufacturing sector contribution to GDP, Employment generation, Wealth Creation and Poverty eradication. The 7 point Agenda, The focus of the Agenda is to put in place policy options and initiatives that would resolve the Infrastructural, Financial and Competitiveness issues facing manufacturers, be it small scale, large scale or even medium scale.

National industrial revolution plan is the latest national roadmap for industrialization in Nigeria with a five year plan. It is hoped that this will accelerate industrial capacity expansions and reform. [12] stated that the main objective of National Industrial Revolution Plan (NIRP) is to move Nigeria beyond been a raw material selling nation into a more value added manufacturing activities nation. The goals of the NIRP among others are; Addition of about N5trillion to annual manufacturing revenues in the next three to five years. Creation of Jobs, Generation of additional National Wealth, Diversification of our economy, Substitution of import, To boost Export, Broaden the nation's tax base.

National industrial development cannot be imported. It must come from within. It is a known fact that we become knowledgeable by learning from others, but we only become wise by understanding ourselves. The NIRP is a five year plan to rapidly build up Industrial Capacity and improve competitiveness in Nigeria.

The plan has identify detail groupings such as Agro-Allied and Agro-Processing, Metals and Solid Materials Processing, Oil and Gas related industries, Construction, Light Manufacturing and other services.

The overriding philosophy of the NIRP starts with the acknowledgment that National Industrializations must be driven by long run competitiveness. This is evidenced by the fact that industries succeed when they are competitive both locally and globally.

What a robust plan, well thought out, well laid out; but one major factor which is key to implementation of the previous plan, and which is, for the current NIRP is the technical and vocational skills. This is because no matter how sound and well thought of a policy plan is acquisition of the right technical and vocational skill to actualize the plan both in quantity and quality is very imperative. This is evidenced from the examples of countries such as Australia, Malaysia and Singapore.

\section{Strategies For National Development}

The beauty of any development plan is the faithful implementation of such plan, which its success lies with the implementers. Key to the success of national development of any nation is the development of strategies for National Development. The focus of this paper therefore is to examine the role of insurance and technical education and national development - a wake up call

\section{TECHNICAL EDUCATION}

Technical which includes Vocational Education and Training has been an integrated part of national development strategies in many countries of the world because of its impact on productivity and economic growth. A nation cannot develop without well-equipped technical and vocational institutions or centers for imparting and training youths and women on practical skills that will yield development in such nation.

According to UNESCO, technical education refers to all forms and levels of the educational process involving, in addition to general knowledge, the study of 
technologies and related sciences and the acquisition of practical skills, know-how, attitudes and understanding relating to occupations in the various sectors of economic and social life.

Also, the National Policy on Education (NPE) defined technical education and vocational education as a comprehensive term referring to those aspects of the educational process involving in addition to general education the study of technologies and related sciences and the acquisition of practical skills, attitudes, understanding and knowledge relating to occupations in various sectors of economic and social life [5].

Technical educational skill therefore refers to any formal training of persons as technicians in different occupations.

[15] reported that technical education refers to the training of technically oriented personnel who will eventually be the initiators, facilitators and implementers of industrial revolution plan of a nation. He concluded that such training will afford the citizen of been technologically literate which will lead to self-reliance and sustainability. Technical educational skill includes, metal work technology, mechanical/automobile technology, electrical and electronic technology, building and woodwork technology, mechtronic technology. e.t.c. Ultimately, technical education will serve as change agents not only for technical systems but also for many other societal changes towards National Development.

\section{A. Experience of Other Countries}

Perhaps, if successive government in Nigeria had adopted technical and vocational education as a vehicle for national development, the nation would have been better for it. The classic examples of the Asian Tiger viz South Korean, Malaysia, Singapore, Indonesia e.t.c to mention the economic giants such as Taiwan, China and Japan that come to mind.

In Malaysia, Technical and vocational skills training are no longer seen as second-class education in Malaysia. Technical education centre (High Schools train students to acquire skills in various area, Technical schools are to train future engineers. There are 33 polytechnics and 86 community colleges under ministry of Higher Education.

Also in South Korea, Technical and Vocational high school in South Korea offer programmes in five fields; Agriculture, technology/engineering, commerce/business, maritime/fishery and home economics. Students in high school follow a common national curriculum. In the second and third year, they follow a course(s) relevant to their specialization. In some programmes, students may participate in work place training through co-operation between schools and local employers. Most vocational high school students continue into tertiary education.

Equally in Australia, Vocational and technical training is mostly post-secondary provided through registered training organization. Some senior schools do offer school-based apprenticeship and traineeships in other more service-oriented occupations. The training provides a combination of school based and work place training. Apprentices and trainees receive a wage which increases as they progress. Training packages are $60 \%$ funded by public funds and training curriculum are define by the need of the industry and not by government and training institutions.

And lastly in Japan, Technical and vocational training offer a 2 year school, to students after finishing high school though not compulsory. In the vocational and training school there are wide ranges of majors such as computer technology, fashion e.t.c.

\section{A.Nigerian Case In Perspective}

The quest for National development, Nigeria want to be a producer nation; that is, producing mainly secondary good rather than primary and crude raw materials. With industrialization, Nigerian wish to transform from a "Consumer Nation". This is because a consumer nation in the emerging competitive world economy is a dying nation. A nation where the standard of living is comparable to the World Standard.

[13] reportedly ask the following questions, do Nigerians need to wear clothes? Then we must have capability to produce some clothes we need to wear, not just raw cottons. Do we need to take good foods and drinks? Then, we must be willing and capable of producing finished goods. Do we need to drive cars? Then, we must not only mine and stockpile iron ore/steel at Itakpe and Ajaokuta, we must have the capability to transform this steel/iron ore into finished goods. It is not sufficient to assemble cars from completely knocked down parts but to manufacture them as is done in Japan, France, and Germany e.t.c

An industrialized Nigeria means, a Nigeria where the average citizens enjoys an appreciable standard of living and that we must produce most of what we consume with substantial leftovers to sell to foreign countries.

Importantly, we must note that general education cannot turn our hides and skins into shoes, or raw cottons into clothes. It is only the relevant technical and vocational skills that are only derived from vocational and technical skill training that will transform wood pulp into paper and our crude oil into a wide spectrum of petroleum consumer goods. Hence, technical and vocational skills acquisition training and not just "general education" are imperative for National development.

For Technical and Vocational skills training to effectively support national development, skills training must be of high quality and competence-based, incorporate the use of modern information and communication technologies, be relevant to the needs of industry, efficient and adaptive to the changing technological work environment.

The skills acquired in technical and vocational educational training is best embodies in the Chinese proverb

'Give a man a fish and he will eat for a day, teach him how to fish and he will eat for a life time "

TVE focused on the formation of skilled workers in technical fields which focus on the skills of the hand (hand-on-skill).

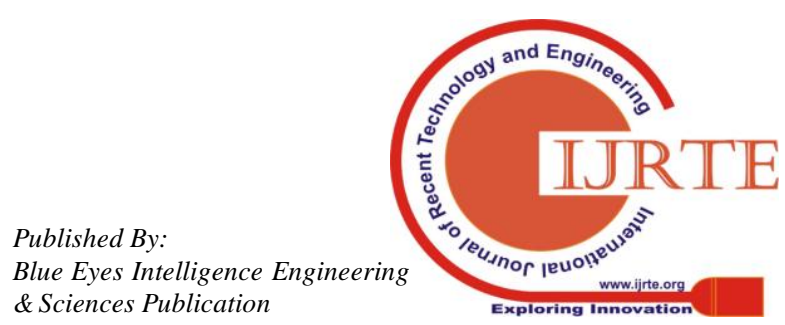




\section{B. Means of Acquiring Technical And Vocational Skills and Training In Nigeria.}

Nigeria is endowed, as the following institutions provide platform for acquiring the skills;

Table I

\begin{tabular}{lccc}
\hline Owners & Polytechnic & $\begin{array}{c}\text { Technical } \\
\text { Colleges }\end{array}$ & $\begin{array}{c}\text { College of } \\
\text { Health } \\
\text { Technology } \\
\text { and Allied } \\
\text { Institutions }\end{array}$ \\
\hline Federal & 28 & 19 & 9 \\
State & 43 & 10 & 40 \\
Private & 54 & Nil & 38 \\
\hline
\end{tabular}

Source: http://www.nbte.gov.ng/institution.html (2019)

This gives a picture of the institutions in Nigeria of Technical Colleges which serves as the entry point for formal training in technical and vocational education while the polytechnics, College of health technology and allied institutions and Universities afforded further training.

The informal training is usually acquired from the artisan - the entrepreneurs, which is industry based training.

After all, the 1997 UNESCO International Standard Classification of Education described Technical and Vocational Education and Training as education and training to acquire the practical skills, know-how and understanding necessary for employment in trade, group occupation or other industrial concerns.

Before the great industrial revolution (1750 to 1830), the home and the "apprenticeship system" constitute the major sources of technical and vocational education.

Without prejudice, the current preoccupation of university education in Nigeria reduces socio-economic opportunities of those who are more oriented towards work life or industry than academics.

Infact, not everyone needs a university education whilst not condemning the General Education. After all, many of the so-called "expatriate engineers" who are adored, well respected and are being paid huge sums of money in dollars to build the roads and bridges or even pilot our industries and other critical sectors in Nigeria are graduates of technical and vocational colleges, yet Nigeria is not taking the sector seriously.

\section{Technical Education And National Development}

This above highlights the importance of the acquisition of technical knowledge, skills and attitudes in any training, hence.

Technical education which includes Vocation is a training and education that relates to a specific trade in which the learner participates and directly develops the society in a particular group of techniques. It is an education that gives individuals the skills to live, learn and work as a productive citizen in a global society. It provides skills, knowledge, attitude and value needed for work place, and prepares learners for career, based on manual and practical activities. The importance of TVET to human development cannot be over-emphasized. Training and capacity building for both

men and women is a key for poverty reduction. Basically, if people lack in technical skills, knowledge and entrepreneurial skills, the natural resources will tend to remain unutilized and underutilized.

Technical Education offers skills aimed at rural development like farm related skills and knowledge, establishment and sustenance of small and medium enterprises directly related to rural needs and demand. This can go a long way in curbing rural-urban migration in Nigeria, as individuals would have skills to keep them occupied in the rural areas.

Technical Education also has the potential to curb high rate of unemployment, especially among the youth and women, as it offers the much needed skills to develop the informal sector in Nigeria. Through Technical Education, individuals are being positioned to develop self-employment, thus reducing pressure on the few available jobs in the formal sector.

Meanwhile, a well developed TVET system in Nigeria will offer a chance to those students who are more comfortable with practical and will also be an alternative to those who drop out of the general academic cycle. In general, TVET gives individuals the skills to live, learn and work as productive citizens in a global society.

\section{Challenges of Technical Education In National Development}

The extent to which Technical Education plays its role in national development is, however, limited by a number of factors. These factors include: people's attitude to technical and vocational training, challenges of developing Nigerian TVET instructors, how to keep pace with technological advancement and poor funding of TVET centers, among others.

It has always been a challenge to change the mindset of parents, the community and industries about vocational education and training being second choice to academic education. Most parents want to see their children becoming engineers, doctors, lawyers etc just because they believe that this will give their children better job opportunities. This challenge is vital to development of TVET sector and it is apparently one of the major obstacles to improve the social status of TVET. Key community, professional and industrial leaders should, therefore, engage constantly in TVET, as this will lead to higher performance and productivity of TVET trained graduates and enhance wages and job opportunities.

There are also many challenges for TVET sector in Nigeria in terms of systematic professional development of instructors and teachers. TVET instructors and teachers are posed with problems on how to use new technology and keep up with teaching methods of various vocational educations. The assistance of analogical TVET teachers to understand and cope with the new digital generation calls for adequate resource investment. 
TVET is also faced with the problem of how to establish technological infrastructure, how to upgrade existing materials and how to train resources available in TVET sector.

Another major constraint that TVET sector faces in Nigeria is inadequate or poor funding. Government's budget on TVET sector is always limited. This becomes the core issues as to why TVET centres in Nigeria are not able to employ trained trainers or support them in updating and upgrading their skills, and as well purchase most appropriate training facilities, aids and technology for practical on-the-job training.

Meanwhile, TVET system in Nigeria is not demand driven. Attachments and linkages to industry are fragile, poorly planned and inadequately supervised. The sector is characterised by outdated curriculum, a mismatch between skills taught and those demanded by the industries, inadequate quality assurance mechanism, inadequate physical and learning resources and low participation of private sector necessary to bridge the gap of school work.

In order to ensure a TVET system that truly contributes to national development or a system that is demand driven, it will be necessary to create a system that is flexible and have a high rate of participation of all concerned parties. This is necessary since the demand for skills is difficult to predict, as technology develops at an ever-increasing rate, and some skills accordingly become obsolete, and others in more demand.

There is need for increased funding toward TVET sector in Nigeria. The fund should be directed toward research and development, acquisition of appropriate and up-to-date equipment and tools, general maintenance and management of TVET institution.

Equal attention or more attention should be offered to TVET sector in Nigeria as that offered to the general education. More TVET institutions should be established in our rural areas with the emphasis on providing technical and vocational skills to meet the needs of the communities. This will reduce rural - urban migration.

In order that TVET is more market driven, it is necessary for the government to involve private organizations in the formulation of the curricular and in the certification of skills offered. Government should also encourage organizations to participate in providing on-the-job training by creating incentives for companies.

In this 21 st century, Nigeria needs to be more inventive and innovative in a way she can develop solutions to her internal problems, especially unemployment. TVET offers such opportunity.

\section{INSURANCE IN NATIONAL DEVELOPMENT}

Insurance as a specialized program and discipline has a place with technical and vocational education gathering.

[9] detailed that insurance organizations influence economic growth and national development by giving assurance to the safeguarded through the channel of peripheral efficiency of capital, mechanical advancement and sparing rate.

[7] opined that the Insurance business is a significant segment of monetary arrangement of the nation expected to drive economic development and industrialization. Additionally, [4] revealed that the genuine esteem that Insurance offers people, organizations and the economy is by giving a feeling that all is well with the world and significant serenity, empowering misfortune relief, expanding success, and for the most part making individuals progressively mindful of the truth of rises and their results through information and pricing signals.

Similarly, [8] revealed that insurance is a risk exchange component whereby the individual and the business endeavor can move a portion of the vulnerabilities' of life on the shoulder of the other. That insurance gives security to trade and industry. This will prompt development and inventions which at last add to human advancement, economies, social and innovative advancement. The above will allow the business the chance to search for new and all the more cutting edge machines, gadgetss and atomic, nuclear innovation and other refined present day hardware that will support the assembling and generation exercises of the economy. He presumed that, without the required insurance spread all modern, economic and social movement of the world will clearly go to a granulating end.

Insurance, a basic livelihood for the accomplishment of supported national development.

\section{A. Insurance Offers Financial Protection Towards National Development Through Promotion Of Sense Of Security And Peace Of Mind}

The genuine esteem that insurance offers individual, corporate association and the economy is by giving a feeling that all is well with the world and significant serenity, empowering misfortune moderation, expanding success and by and large making individuals increasingly mindful of the truth of risks and their outcomes through information and pricing signals.. Insurance additionally oversees, expands and ingests the risks of people and organizations.

Insurance is subsequently seen as a precondition for the development of other profitable activities, for example, beginning and expand a business. In this way these activities fuel demand, encourage supply and at last help exchange.

\section{B. Insurance Act As Stabilizing Factor}

This is accomplished by the characteristic result of its social security value. A protected individual who does not endure undue money related misfortune after an unexpected disaster will all the more effectively keep up his buying influence. The total effect of insurance in this manner is to level utilization designs and contribute all the more generally to budgetary and social security. This stabilizing factor is fortified by the job of insurance as a long term financial specialist in undertaking and business.

\section{and Engin}




\section{Insurance As An Institutional Investor}

This the insurance does by directing reserve funds into long term ventures and giving more noteworthy straightforwardness and liquidity to the business sectors, consequently giving further help and growth to the economy.

\section{Insurance Promoted Public Safety And Engender New Product Development}

This Insurance does by bringing issues to light about security, prompting improved wellbeing prerequisite that spare lives, properties and fuel advancement in the assembling segment (for example vehicle insurance and safety belts, family unit insurance and flame avoidance ,designing insurance and sprinkler framework) e.t.c.

\section{E. Insurance Enhances Financial Security As Well Peace Of Mind}

Insurance empowers families and organizations to remain financially stable even with hardship which is the essential social assurance system of insurance that has numerous constructive outcomes. It sustain standard of living and not too bad personal satisfaction after retirement (annuity, particular kinds of life coverage items and long term care insurance).

In guaranteeing business as a going concern, it will endeavor to avert business intrusions that may result in liquidations prompting breakdown which thus result in occupation misfortune and economic hardship for employees with its chaperon multiplier impact of employees' dependant.

\section{F. Insurance Promotes Social Welfare And Security}

The concentration here is the arrangement of pension or retirement benefit. Developed economies not to mention developing economies that are confronting real sovereign debt issues while the social welfare bundles which is progressively burdening national spending plans. Similarly spending on open annuity is cosmic, and human services spending aren't saved. In all the over, a significant sum or rate in budgetary arrangement; which clearly will have untold impact on the capacity of government to give the basic administrations of the state. The insurance area in this way can assume a significant job in helping states give security to natives while reducing their money related weights. The insurance will contribute its experience and ability in risk the executives to offer reciprocal items and administrations and help structure answers for these imposing difficulties.

\section{G. Insurance Role In Risk Management}

Past offering insurance security against different exposures, the insurance business offers an important administration of risk the executives' abilities and guidance that advantages society in general. Risk supervisors are in guardianship of enormous amount of research on what establish and adds to risk in numerous regions and over a wide range of orders, for example, building, development, fabricating, wellbeing, money, geography, education e.t.c.

The aftereffect of such research send estimating signals that pushed numerous open discussions on wellbeing, which frequently prompts wellbeing improvement conduct with respect to the purchaser and even support more extensive and better legitimate standards, for example, improved security execution prerequisite for vehicles, fire alerts and sprinklers or security frameworks for homes and organizations construction standards to ensure our homes. Data that will decrease the quantity of useless ventures.

Risk the executives offers both pre occasion guidance and data which endeavor to keep the occasion from taking spots to post - occasion risk the executives data which try to contain the impact that is, "ex-bet" conduct which is more useful to all gatherings than ex-post conduct which can just decrease the effect of the misfortune.

At last the guaranteed and back up plans progress in the direction of the shared objective of risk management which is to accomplish powerful counteractive action in an inexorably intricate societal condition. Actually in certain cases, organizations' risk improvement looking over and counsel could really compare to taken insurance cover.

\section{CHALLENGES OF INSURANCE TOWARDS NATIONAL DEVELOPMENT}

For example to have the option to contribute adequately towards the accomplishment of national development in Nigeria, consideration must be paid to the accompanying components:

\section{A. Inadequacy In The Number Of Institutions Offering Insurance}

The quantity of higher institutions offering insurance as a course of study are too few contrasted with the staff need, either in the insurance industry, the modern and manufacturing sector or of significance those institutions preparing them. By and by just a single establishment offers post graduate study on insurance. We need more institutions.

\section{B. Review Of Insurance Curriculum}

For the insurance area to have the option to assume its job successfully in national development, Insurance educational programs of our institutions of higher learning must be explored and improved to mull over the headway and innovation in our economy. Prospectus of the majority of them is out of date, they need a critical audit even with current substances.

\section{Industry Capacity}

The absolute insurance industry limit must be expanded; these will be regarding the capital base, the re-insurance arrangement, hi-tech insurance custom fitted items and the general extension of insurance industry frontiers. 


\section{Insurance Industry To Brace Up For Challenges} Ahead

The insurance business player ought to acknowledge the undertaking of gathering the different insurance and insurance related needs of national development as difficulties ahead.

\section{E. Review And Implementation Of Regulatory Framework}

For insurance to have the option to effectively assume its ideal job in the national development, the insurance administrative structure should be reinforced as far as innoative insurance products inclusion for the complex modern procedure and the business player to play by the standard rules.

\section{F. Need For Government Attitudinal Change}

As of not long ago, governments at different dimensions pay lip administration to insurance administrations and the insurance sector by and large. With the downturn in the economy event by the drop in petroleum cost around the world, there seem, by all accounts, to be a beam of expectation. Government is the biggest indebted person of insurance premium, most property of government are not guaranteed notwithstanding when safeguarded premium are not paid.

\section{G. Staff Situation In The Institutions Offering Insurance}

Staff circumstance in the institutions offering insurance, the road for post-graduate study and research is confined in actuality just two college run post graduate program in insurance and risk the board consider. This is even on a constrained premise as the staff circumstance in the college, just had 6 Ph.D in Insurance or Risk Management. In this manner, except if the staff circumstance improves, even to render consultancy benefits, a great deal of weight is put on the not very many hands accessible. This will affect on the capacity of the insurance segment to assume its job successfully in the accomplishment of national development.

\section{WAY FORWARD}

Powerful technical and vocational education and preparing for national development is just conceivable if all the significant partners have their impact [1]. As further distinguished, the partners to incorporate; Government, Training Institutions, Parents and Guardians, Development accomplices and Employers, all have significant task to carry out.

\section{A. Government}

(i) Develop and support implementation of national TVET policies, (ii) Improve coherence of governance and management, (iii) Introduce policies and incentives that will support increased private sector participation in TVET delivery, (iv) Improve capital investment in TVET, (v) Establish TVET management information system for education and training, (vi) Create measures to reduce gender, economic and geographical inequities in TVET provision, (vii) Ensure sustainable financing scheme for TVET, (viii) Increase funding support for the sector, (ix) Mainstream TVET into the general system so that the vocational track is less dead-end, (x) Constantly monitor and periodically evaluate the performance of the system and apply corrective measures where need be.

\section{B. Educational institutions and training providers}

(I) Provide training inside national policy structure. (ii) Deliver an adaptable and demand-driven training. (iii) Develop marketable strategy to help training activities. (iv) Establish solid linkages and joint effort with managers and industry. (v) Mainstream sexual orientation in preparing activities and projects. (vi) Introduce ICT in training. (vii) Institute bursary plans for poor trainees (viii) Strengthen direction and guidance to students. (ix) Network and bench mark with other training providers. (x) Involve communities, guardians and parents in training activities. (xi) Training establishments ought to be urged to be profit orienteded and to become dynamic operators in the training market.

\section{Home fronts}

(I) Support kids and wards to pursue a vocation in TVET track. (ii) Reject discernment that vet is for the less scholastically blessed (iii) Lobby lawmakers for TVET. (iv) Support activities of educational establishments and training providers.

\section{Donors And Development Partners}

(I) Support development and execution of national TVET arrangements and systems. (ii) Fund private venture development inquire about. (iii) Fund obtaining of preparing hardware. (iv) Support post-preparing work bolster administrations for TVET graduates, including business new companies. (v) Support limit working in TVET area educator preparing, the executives preparing, technical help e.t.c. (vi) Help in recognizing and dispersing best practices in TVET. (vii) Support TVET backing activities, inspiration crusades and projects.

\section{E. Employers}

(I) Deliver work spot preparing to employees. (ii) Contribute financially to national preparing reserve. (iii) Provide openings in industry for TVET educators to routinely refresh their work spot involvement. (iv) Provide open doors for mechanical connection and temporary positions for students. (v) Contribute to the development of national aptitude standards

The accomplishment of improved and feasible development through technical and vocational abilities preparing demands arrangements and techniques that tends to the cross-cutting issues of value and significance of preparing, employability, joint effort between preparing foundations and managers, accreditation of training providers (in the formal, non-formal and casual parts), appraisal, 
affirmation, inside and outer quality confirmation of training projects, financing, and educator preparing.

This requires a TVET framework that is skilled based and business driven with capability testing of the students and learners as a proof of ability. TVET ought to likewise be seen and recognize by every one of the partners as a legitimate visa to a generously compensated activity or independent work or advanced education which is exceptionally basic for national development and not as an option educational open door fit distinctly for early school leavers, the less scholastically invested or even poor people.

On a last note, it is essential to make the point unmistakable that technical and vocational education and training is fundamental yet not by any means the only means for accomplishing national industrial development. Great government arrangements that animate the economy and grow high performance enterprise. For this to be accomplished on a feasible premise, TVET framework must be lab labour-market relevant, equitable, efficient and of high quality.

\section{CONCLUSION}

Achieving improved and sustainable National development is quite possible if all the stake holders pay desired attention to technical education and insurance training as obtained in the developed and developing nations of the world.

\section{ACKNOWLEDGEMENT}

I acknowledge the contributions of Mr. Noah G. Alli of Insurance Department, Federal Polytechnic Offa to ensure the manuscript see the light of the day. Also, the effort of Raji

\section{REFERENCES}

[1] G. Afeti, "Technical and vocational education and training for industrialization". http://www.arrforum.org/publication/, 2011.

[2] I. Aremu. "Development and political stability in kwanashie (ed) politics and political power relations in Nigeria". Lagos. Dat and Partners Logistic Ltd, 12: 2003, pp. 248-262.

[3] J.J. Chrisman. "Manufacturing techniques small companies can really use". Wisconsin Small Business Forum, 3(1) 1984, pp. 1 - 14

[4] M, Cleric, W. Deller and Bowank. "The social and economic value of insurance. A Geneva Association Papers Risk and Insurance Economics", 2012, pp 5-13.

[5] Federal Government of Nigeria. "National policy on education". Federal Government Press Limited, 1981. Lagos. pp $1-8$.

[6] A. Gboyega. "Democracy and development: the imperative of local governance," 2003, An Inaugural Lecture, University of Ibadan, pp 6-7.

[7] N.O. Iwaela. "Insurance news", the nation newspaper, Vintage Press limited, Lagos, 2015, pp $35-38$.

[8] Z.A. Khan. "Importance of Insurance in our economy, Articles, Features \& Revie"w, Google, 2014. pp 18-19

[9] O. Momoh. "Impact of the Nigerian insurance industry on sustainable economic growth and development". International Journal of Management and Social Science Research. 2018, Vol. 7(4)

[10] O. Naomi, "Towards an integrated view of human hunger". Tech. Net.1995 6(3) 6-7

[11] NBTE. "Statistical Data on Institutions in Nigeria". 2019 Accessed from http://www.nbte.gov.ng/institution.html

[12] NIRP, "Nigeria Industrial Revolution Plan". A Publication of the Federal Government of Nigeria Press 2014.

[13] C.D. Obeifuna. "Industry-based apprentice training in Nigeria". TRADEV - Journal of Training and Development, ICD, 199845 - 48.
[14] F. Ogwumike, "The effects of macro level government policies on rural development and poverty alleviation in Nigeria". Ibadan J. Soc. Sci., 1995 1(1): 85-101.

[15] V.O. Uwaifo, "Technical Education and its Challenges in Nigeria in the 21 st Century". International NGO Journal Vol 5.(2) 2009, Pp. 40-4

\section{AUTHORS PROFILE}

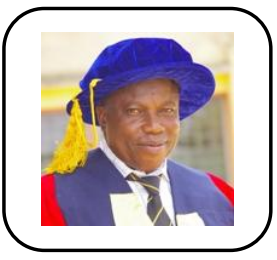

Raji Sarafa Adebayo has a B.Sc (Hons) in Insurance from University of Lagos in 1989, Masters in Business Administraton in 1996 and M.Sc in Management Science in 2006 both from University of Ilroin, Kwara State, Nigeria and capped it with Ph.D in Management Science from Ladoke Akintola University of Technology, Applied Management Science.

$\mathrm{He}$ is an associate, chartered insurance institute of nigeri by examination and a Fellow of Institute of operations Research (FIOR). He had about a decade in Insurancee Industry at both Gateway Insurance P.L.C and Metropolitan Trust Insurance PLC, Lagos. Currently, he is the director, Academic Planning Unit, Federal Polytechnic Offa, having headed various position in the past. He is an erudite and prolific writer. His research interest include Health Sector Planning, Insurance underwriting, Marketing, Educational Planning and Management. 